\title{
Environmental Kuznet's Curve for Saudi Arabia: An Endogenous Structural Breaks based Cointegration Analysis
}

\author{
Mohammad Asif \\ Dept. of Economics, Aligarh Muslim University \\ Aligarh-202002, India \\ Tel: 91-571-270-0689Ｅ-mail:m.asif.ec@amu.ac.in
}

Received: September 22, 2017 Accepted: November 20, 2017 Published: November 27, 2017

doi: $10.5296 /$ jsss.v5i1.12196

URL: http://doi.org/10.5296/jsss.v5i1.12196

\begin{abstract}
The study attempts to analyse cointegrating relationship between carbon emissions, energy consumption, income and trade openness in case of Saudi Arabia using the time series data for the period 1971-2011. For this purpose, it uses the ARDL cointegrating technique to find out the long run relationships among the variables. The bounds test results indicate that there exist long- run relationships between the variables. The study also used threshold cointegrating test in order to test the environmental Kuznet's curve hypothesis in the presence of regime shift. This study confirms existence of cointegrating relationship in case of single structural break, but for two structural break there is no cointegration among the variables. The Environmental Kuznet's curve hypothesis does not hold in Saudi Arabia. The study does not find long run coefficients statistically significant except for trade openness.
\end{abstract}

Keywords: Carbon emissions, Energy consumption, Threshold cointegration, Environmental Kuznet's curve

\section{Introduction}

The Environmental Kuznets curve (EKC) hypothesis that aims to establish the relationship between environmental pollution and economic growth plays central role in the formulation of efficient energy policy. According to EKC hypothesis, at the initial phase of economic growth and development an economy witnesses a positive relationship between economic growth and environmental pollution and after reaching some threshold level of economic growth, environmental pollution begins to decline. Under this assumption, the EKC hypothesis is considered as an inverted U-shaped curve, exhibiting the relationship between environmental 


\section{Macrothink}

degradation and economic growth of an economy. In the literature, studies have shown that EKC hypothesis is determined by scale, composition and technique effects (Kanjilal \& Ghosh, 2013). In the scale effect, it is assumed that higher environmental degradation is strongly linked with higher economic activity; this appears to be highly relevant in the initial phases of economic growth and development in an economy. As the economy expands, industries gradually start adopting cleaner technologies, reducing the share of pollution intensive products in the production process. The latter is known as 'composition' effect whereas the former is regarded as 'technique' effect. A close survey of existing studies on EKC reveals that a large number of studies have been undertaken to validate the existence of EKC in cases of developed as well as emerging economies. Unfortunately, a limited attention has been paid to investigate the existence of EKC hypothesis in case of Gulf Cooperation Council (GCC) countries. The possible explanation could be because of unavailability of large sample data and less priority given by researchers due to the limited contribution of these economies in the global carbon emission. But in recent year, owing to continuous monitoring of carbon emission across countries by United Nations Framework Convention on Climate Change (UNFCC), the issue of climate change has become a global issue and has garnered the considerable attention of regulators and researchers to undertake necessary measures to reduce the carbon related emissions from the existing level. Considering these issues into account, the present study attempts to test the EKC hypothesis in the context of possible regime shifts in cointegrating relationship between $\mathrm{CO}_{2}$ emission, energy consumption, economic growth and trade openness for Saudi Arabia. The sample period of the study is 1971-2011. This may be a significant contribution to the existing literature in case of Saudi Arabia as there is no study as per my knowledge that has examined such relationship in cointegration framework by taking into account the possible endogenous structural break in the data. The present study promises to add value to the existing literature.

The present study is motivated to study the extent to which economic growth is linked with environmental degradation in case of Saudi Arabia. As per the reports of US Energy Information Administration (EIA, 2008), Saudi Arabia has been ranked 11th among the major carbon emitting countries in the world. At the same time, it is also the second largest (after Iran) in terms of carbon emission in the Middle East region. According to recent data on $\mathrm{CO}_{2}$ emission, among all Middle East nations, the percentage share of Saudi Arabia in 2011, is more than $26 \%$ (see EIA, 2011). With respect to year on year growth rates, in 2011, the growth rate of carbon emission has been around 9.5\% higher than the last three years. One of the reasons of such a high growth in carbon emission could be because of strong surge in economic activities supplemented by high energy demand and heavy exploration of hydrocarbons in order to meet the sudden rise in global demand. In recent year, Saudi Arabian economy has witnessed strong boom in real estate and manufacturing activities, as there is strong emphasis of reducing the oil dependence in coming years to a sustainable level. The major sources of carbon emission are oil related sectors, electricity generation, the solid waste management, and the agricultural sectors (see Rahman, 2012). Even though Saudi Arabia is the world's largest producer of crude oil, not surprisingly, the hydrocarbons are one of the major sources of fossil-fuel $\mathrm{CO}_{2}$ emissions (Boden et al., 2011). These figures are really surprising especially at the time when environmental degradation is a hotly debated issue. These figures also clearly reveal that Saudi 
economy faces the challenge of balancing act between economic growth and environmental degradation like other major economies in the GCC region and across the world. In order to sustain the high economic growth, Saudi's economy must emphasize on reducing the environmental degradation from the existing level. In this regard, the technological innovation and design and implementation of environmental policy can play pivotal role in shaping up the fragile nature of the environmental degradation. In the literature, studies have shown that the successful implementation of environmental regulations is strongly linked with the pattern of economic growth and development and is the basis of environmental Kuznet's curve (EKC) hypothesis which has garnered considerable attention of empirical research in the past decades (see Stern, 2004). The recent studies have also added the new dimension of research by way of applying the recently developed time-series and panel data econometric models. In this respect, the present study will add value to the existing literature by providing a new dimension (application of endogenous structural break models) of EKC research in case of Saudi Arabia. The study appears to be promising from the perspective of environmental policy because it has added new avenues in the area of sustainable environmental policy research that may also be a basis for other GCC countries.

\section{Review of Literature}

There is huge wealth of literature available on examining the nexus between carbon emission, energy consumption and economic growth. For the ease of better exposition, these studies can be divided into three different streams based on the objectives and outcomes. The first stream focusses upon exploring the relationship between energy consumption and economic growth. The central issue has been whether economic growth augments energy consumption or energy consumption itself drives economic growth via the indirect channels of aggregated effective demand, technological progress and overall energy efficiency. In this regard, (Kraft, 1978) in their study exhibited the causal relationship between energy consumption and economic growth. Later work also reported the similar empirical inference, some of which include (Akarca \& Long 1980), Yu and Hwang (1984), Yu and Choi (1985), Erol and Yu (1987), Abosedra and Baghestani (1989), Bentzen, Engsted (1993). As highlighted by Stern (1993) these studies suffer from specification biases due to small sample size and omission of relevant variables. Recent literature on examining the nexus between energy consumption and economic growth under multivariate framework are Stern (2000), Soytas and Sari (2003, 2006, 2009), Ghali and El-Sakka (2004), Altinay and Karagol (2004), Oh. and Lee (2004) Wolde-Rufael (2005), Akinlo (2008); Narayan and Smyth (2005),Apergis and Payne (2009) among others. In this regard, Brown and Yucel (2002) provide a detailed survey of the theory and evidence on the macroeconomic impact of energy prices. Huang et al. (2008) provide a comprehensive literature survey on the empirical findings from energy-economic growth causality results. A close re-appraisal of existing literature reveals that the role of energy consumption in economic growth have reported mixed results across sample countries and periods.

Second thread of research focuses on the relationship between economic growth and environmental degradation, where the researchers have investigated the existence of EKC hypothesis covering developed and emerging economies. In this line of research, the first seminal study was proposed by Grossman and Krueger (1991) followed by a series of studies 
viz., Shafik, (1994), Heil and Selden (1999), Friedl and Getzner (2003), Dinda and Coondoo (2006), Managi and Jena (2008), Coondoo and Dinda (2008), Romero-Avila (2008), Akbostanci et al. (2009), among others. With regard to EKC literature, Stern (2004) and Dinda (2004) provided a comprehensive literature review. However, despite such a large volume of literature, the results are still inconclusive and provide further scope of re-examination.

Finally a third stream of research has emerged, which combines the first and second streams by investigating the dynamic relationship between carbon emissions, energy consumption and economic growth. Some of the important studies in this field include Soytas et al. (2007), Ang (2008), Soytas and Sari (2009a, 2009b), Zhang and Cheng (2009), Halicioglu (2009), Jalil and Mahmud (2009), Ghosh (2010).

Studies concerning Saudi Arabia, researchers have paid very limited attention on investigating the existence of EKC for Saudi Arabian economy. To the best of our knowledge, there is only one study that attempted to investigate the existence of EKC in case of Saudi Arabia. Mansur and Mello (2011)in their study examine the relatinship between carbon emission and GDP per capita for Saudi Arabia. The sample period of this study was 1975-2003. The main objective of this study was to confirm whether EKC hypothesis is applicable in case of Saudi Arabian economy. They applied Long Run Structural Modelling (LRSM) technique. The findings of this study suggested the long-run relationship between carbon emission and economic growth and exhibtied the existence of N-shape EKC. In the light of the review of the above mentioned streams of existing studies and literature on Saudi Arabia, the present study is expected to add value to the existing literature in following manner:

1) In the context of Saudi Arabian economy, this is the first study that highlights the role of structural breaks in the EKC analysis. This is mainly because with the help of structural break, it is easier to capture impact of economic crises, technological shocks, external shocks or policy changes on the existence of EKC hypothesis.

2) Besides this, the incorporation of structural break in empirical analysis may also provide insight about the possible reason of long-run disequilibrium between the underlying variables.

3) In addition, the analysis of structural break often provide strong argument against the conventional cointegration assumption that the cointegrating relationship remain same during the period under consideration.

4) With the use of recent data, the study attempts to capture the impact of recent policy measures with regard to carbon related emission.

5) In recent years, climate change has become dominant policy issue with global appeal. In this light, it is imperative for every economy to undertake research related with carbon emission and its impact on economic growth. So that pragmatic policy measures could be annocuned. Since Saudi's economy is also one of the largest emitter of carbon gas, hence, this study will be a guiding tool from policy persepctive. 


\section{Macrothink}

6) With the incorporation of Saudi's export and import, the study tries to exhibit the impact of trade openness and oil export on carbon emission as oil sector is considered to be the largest emittor of $\mathrm{CO}_{2}$ in the country

\section{Objectives of the Study}

The major objectives of this study is:

1) To examine the long-term relationship between $\mathrm{CO}_{2}$ emission, energy consumption, economic activity and traded openness for Saudi Arabian economy;

2) To re-visit the cointegrating relationship by employing cointegration test with endogenous structural break. This is mainly to validate the EKC hypothesis in the presence of possible endogenous structural break in the existing long run relationship of sample variables.

3) To confirm whether EKC hypothesis is applicable for Saudi Arabia.

4) To study the identified structural breaks from policy perspective.

5) To study the policy implications of EKC hypothesis in case of Saudi Arabia.

\section{Data and Research Methodology}

\subsection{Data}

In this study, $\mathrm{CO}_{2}$ emissions (metric tons per capita), Energy use (kg of oil equivalent per capita), GDP per capita (constant 2005 US\$), Exports and Imports as \% of GDP are retrieved from World Development Indicators (WDI).The sample period of this study is 1971-2011. In case of other observations, the study has retrieved the data from the websites of Saudi Arabian Monetary Authority (SAMA) and EIA.

\subsection{Empirical Methodology}

At first stage of empirical analysis, the study has applied the tests of unit root to confirm whether the sample data are stationary or not. For this purpose, three different variants of unit root tests viz., Augmented Dickey and Fuller (1979), Phillips and Perron (1988) and Dicky and Fuller Generalized Least Square (DF-GLS unit root tests developed by Elliot et al. (1996) has been applied. Generalized Least Square (DF-GLS unit root tests is an efficient and modified version of conventional ADF test that is based on the detrended variable. Apart from these the study has also used unit root test with breakpoint by Perron (1989). Based on the inference obtained from these tests, the study has inferred that the variables are nonstationary at levels but stationary at first difference. After the test of stationarity, the study uses Auto-Regressive Distributed Lag (ARDL) model to test the cointegration among the variables. It may here be noted that unlike Johansen's cointegration, the test of stationarity in case of Autoregressive Distributed Lagged (ARDL) model is not a pre-requisite criterion due to the presence of lower and upper bounds. In other words this model is used even with a mix order of integration.

\subsubsection{The Model}

Following Halicioglu (2009) and Kanjilal and Ghosh (2013), the study specifies the following linear logarithmic quadratic functional form for long run relationship among carbon emission, energy consumption, economic activity and trade openness for the country.

$$
\begin{aligned}
& C O_{2}=\phi_{0}+\alpha_{1} Y_{t}+\alpha_{2} Y_{t}^{2}+\alpha_{3} E N_{t}+\alpha_{4} T O_{t}+\varepsilon_{t} \\
& t=1,2, \ldots . n
\end{aligned}
$$


Where $C \mathrm{O}_{2}, Y_{t}, Y_{t}^{2}, E N_{t}$ and $T O_{t}$ denote the per capita carbon emission, per capita GDP, square of per capita GDP, per capita energy use and trade openness, respectively, after logarithmic transformation.

- If the EKC hypothesis is true, the expected sign of $\alpha_{1}$ is positive and $\alpha_{2}$ is negative. The statistical significance of $\alpha_{2}$ implies that a monotonically increasing relationship between per capita carbon emission and income.

- The sign of per capita energy use $\alpha_{3}$ is expected to be positive as higher energy consumption leads to higher carbon emission.

- The expected sign of $\alpha_{4}$ may either be mixed because it is strongly linked with the stages of growth and development and environmental aspects of production process of an economy (see Grossman and Krueger, 1991).

- The expected sign of trade openness is also dependent upon the nature of economy. For an import dependent country, the sign of trade openness may either be negative and vice-versa.

Table 1. Descriptive statistics

\begin{tabular}{llllll}
\hline & $\mathrm{CO} 2$ & $\mathrm{Y}$ & $Y^{2}$ & $\mathrm{EN}$ & $\mathrm{TO}$ \\
\hline Mean & 2.644436 & 9.582885 & 91.87898 & 8.143262 & 4.341453 \\
Median & 2.6406 & 9.493536 & 90.12723 & 8.37412 & 4.324448 \\
Maximum & 2.943261 & 9.99888 & 99.97759 & 8.794829 & 4.792641 \\
Minimum & 2.283502 & 9.348854 & 87.40106 & 6.886964 & 4.033784 \\
Std. Dev. & 0.161146 & 0.220178 & 4.259087 & 0.544373 & 0.164685 \\
Skewness & -0.26876 & 0.815774 & 0.832758 & -1.21843 & 0.278749 \\
Kurtosis & 2.516925 & 2.170083 & 2.193893 & 3.120179 & 2.735558 \\
\hline
\end{tabular}

\subsubsection{Cointegration Methodology}

Like conventional tests of cointegration such as Engle and Granger (1987) and Johansen and Juselius (1990) which have been used widely in empirical research to examine the long-term relationship of variables under consideration in a bivariate or multivariate framework and having several advantages, one of the drawbacks of conventional cointegration is that it assumes strict non-stationarity of an economic variable, failing which the model is not recommended to estimate. In order to overcome this methodological drawback, ARDL bounds tests approach for cointegration (Pesaran et al., 2001) is becoming increasingly popular in empirical research due to its several methodological advantage. First, it can be employed regardless of whether the underlying variable is I (0) or I (1). Second, there is advantage of simultaneous estimation of long 
and short-run parameters in a model. Third, the small sample properties of ARDL are superior to that of multivariate cointegration (Narayan, 2004).

One of the major drawbacks of conventional cointegration tests is the assumption that the cointegrating relationship is not time-varying even in the case of large sample series. Besides this, the cointegration results may be suspected when the sample period under analysis may have witnessed major events (e.g., a global economic crisis such as sovereign debt defaults, currency devaluation, domestic policy upheavals, regulatory shocks, etc.), which are likely to create structural breaks in a particular series. Since conventional cointegration tests are not applicable to exhibit the long-run relationship especially when structural breaks are present in sampled series. Hence, it is always recommended to estimate the Gregory and Hansen (henceforth, GH, 1996) and Hatemi-J (Henceforth, 2008) cointegration test to estimate the variables. This is mainly because these tests are able to identify the presence of structural breaks in a long time series that may change the cointegrating relationship. In other words, the long run relationship is likely to witness one or two regime shifts in the sample period. In that case, conventional cointegration tests, as stated above, may suffer from specification bias and provide misleading results. In this light, this study uses the ARDL bounds test cointegration methodology followed by $\mathrm{GH}$ and $\mathrm{HJ}$ threshold cointegration tests to examine EKC hypothesis for Saudi Arabia.

\subsubsection{ARDL Model Specification}

An ARDL model is a general dynamic specification, which uses the lags of the dependent variable and the lagged and contemporaneous values of the independent variables, through which the short-run effects can be directly estimated, and the long-run equilibrium relationship can be indirectly estimated, removing problems associated with omitted variables and autocorrelation. ARDL technique involves estimating unrestricted error correction model. An ARDL representation of Eq. (1) is given as follows:

$$
\begin{aligned}
& \Delta C O_{2}=\alpha_{0}+\sum_{i=1}^{n} \beta_{1} \Delta C O_{2 t-i}+\sum_{i=1}^{n} \beta_{2} \Delta Y_{t-i}+\sum_{i=1}^{n} \beta_{3} \Delta Y_{t-i}^{2}+\sum_{i=1}^{n} \beta_{4} \Delta E N_{t}+\sum_{i=1}^{n} \beta_{5} \Delta T O_{t}+ \\
& \gamma_{1} C O_{2 t-1}+\gamma_{2} Y_{t-1}+\gamma_{3} Y_{t-1}^{2}+\gamma_{4} E N_{t-1}+\gamma_{5} T O_{t-1}+\varepsilon_{1 t} \ldots \ldots \ldots \ldots \ldots . . .(2)
\end{aligned}
$$

F-test is used to find out whether a cointegrating relationship exists among the estimated variables. The null hypothesis of no cointegration among the variables in Equation (2) is

$$
H_{0}: \gamma_{1}=\gamma_{2}=\gamma_{3}=\gamma_{4}=\gamma_{5}=0 \text { against } H_{1}: \gamma_{1} \neq \gamma_{2} \neq \gamma_{3} \neq \gamma_{4} \neq \gamma_{5}
$$

which is denoted as $\mathrm{F}_{\mathrm{CO}_{2}}\left(\mathrm{CO}_{2} \mid Y, Y^{2}, E N, T O\right)$. Two sets of critical F-values have been provided by Pesaran and Shin (1998) and Pesaran et al. (2001) for large samples, Narayan (2005) for sample size ranging from 30 to 80 and Turner (2006) for response surface analysis, where one set assumes that all variables in ARDL model are I (1) and another assumes that all variables are I ( 0$)$ in nature. If the calculated F-statistics is greater than the band, a conclusive decision can be taken without prerequisite of whether the underlying variables are $\mathrm{I}(0)$ or $I(1)$. If the computed F-statics falls within the critical band, inference remains inconclusive. Further, once the orders of the lags in the ARDL model have been appropriately selected, one can estimate the cointegration relationship using a simple Ordinary Least Square (OLS) 
method.

\subsubsection{Threshold Cointegration Approach}

GH and HJ have considered 'Level Shift (C)', 'Level Shift with Trend (C/T)' and 'Regime Shift $(\mathrm{C} / \mathrm{S})^{\prime}$ ' models to test possible structural breaks in cointegration tests. This study considers Regime Shift model both for GH and HJ cointegration tests. GH test has taken one break point whereas $\mathrm{HJ}$ has incorporated two break points. The regime shift model representation of Eq.(1)for $\mathrm{GH}$ and $\mathrm{HJ}$ tests which incorporate structural breaks on both intercept and slope are defined as:

GH Test:

$$
\begin{aligned}
& C O_{2}=\phi_{0}+\alpha_{1} D_{1 t}+\alpha_{01} Y_{t}+\alpha_{11} D_{1 t} Y_{t}+\alpha_{02} Y_{t}^{2}+\alpha_{12} D_{1 t} Y_{t}^{2}+ \\
& \alpha_{03} E N_{t}+\alpha_{13} D_{1 t} E N_{t}+\alpha_{04} T O_{t}+\alpha_{14} D_{1 t} T O_{t}+\varepsilon_{t}
\end{aligned}
$$

HJ Test:

$$
\begin{aligned}
& C O_{2}=\phi_{0}+\alpha_{1} D_{1 t}+\alpha_{2} D_{2 t}+\alpha_{01} Y_{t}+\alpha_{11} D_{1 t} Y_{t}+\alpha_{21} D_{2 t} Y_{t}+\alpha_{02} Y_{t}^{2}+\alpha_{12} D_{1 t} Y_{t}^{2}+\alpha_{22} D_{2 t} Y_{t}^{2}+ \\
& \alpha_{03} E N_{t}+\alpha_{13} D_{1 t} E N_{t}+\alpha_{23} D_{2 t} E N_{t}+\alpha_{04} T O_{t}+\alpha_{14} D_{1 t} T O_{t}+\alpha_{24} D_{2 t} T O_{t}+\varepsilon_{t} \ldots \ldots \ldots . . .(4)
\end{aligned}
$$

$\alpha_{1}$ is the differential intercept over the common intercept $\phi_{0}$ with single structural break for Equation (3) but differential intercept over the common intercept for the first sub-sample of structural break for Equation (4). $\alpha_{2}$ is the intercept differential over the common intercept $\alpha_{0}$ for the second sub-sample of structural break for Equation (4). $\alpha_{0 i}$ is the coefficients for ith independent variable $i=1,2,3,4 . \quad \alpha_{1 i}$ is the differential slope coefficient over the base slope coefficient over the base slope coefficient $\alpha_{0 i}$ with single structural break for Equation (3) but for Equation (4) differential slope coefficient over the base slope coefficient $\alpha_{0 i}$ is for the first sub-sample of structural break $i=1,2,3,4 ; \quad \alpha_{2 i}$ is the differential slope coefficient over the base slope coefficient $\alpha_{0 i}$ for the second sub-sample of structural break for Equation (4). $D_{1 t}$ is the dummy variable for the endogenous structural break at time $\mathrm{t}=1,2, \ldots$, n for Equation (3), but for Equation (4), dummy variable to represent the first endogenous break. $D_{2 t}$ is the dummy variable representing the second endogenous structural break at $\mathrm{t}=1$, $2, \ldots \ldots, \mathrm{n}$ for Equation (4). 


$$
\begin{aligned}
D_{1 t} & =0 ; & & \text { if } \mathrm{t}<\left[\mathrm{n} T_{1}\right] \\
& =1 ; & & \text { if } \mathrm{t}>\left[\mathrm{n} T_{1}\right] \\
D_{2 t} & =0 ; & & \text { if } \mathrm{t}<\left[n T_{2}\right] \\
& =1 ; & & \text { if } \mathrm{t}>\left[\mathrm{nT}_{\mathfrak{1}_{2}}\right]
\end{aligned}
$$

are the dummy variables with the known parameters $T_{1}$ and $T_{z}$ belonging to the 0,1 meaning the relative timing of regime change point or structural break points which are not known a priori. The standard methods of testing the null hypothesis of no cointegration in the context of Equation (3) and Equation (4), when there are no dummies for structural breaks are residual based approach of Engle and Granger(1987). GH has shown that residual based tests namely Augmented Dicky- Fuller (ADF) and $Z_{\alpha}, z_{\varepsilon}$ test proposed by Perron (1989) applied to regression errors to test the null hypothesis of no cointegration leads to misspecification of cointegration if the structural breaks are unknown. GH has however used an advanced nonlinear cointegration test with a structural break which is considered as multivariate extension of univariate ZA unit root test. Gregory-Hansen (1996) proposed a residual based cointegration test (GH-test) that takes into account regime shifts either in the intercept or the entire vector of coefficients. They proposed biased -corrected modified ADF*, $Z_{\Omega}{ }^{*}$ and $Z_{t}{ }^{*}$ for testing cointegration of the above variables.

$\mathrm{ADF}^{*}=\inf \operatorname{ADF}(\tau)$

$$
\begin{aligned}
& (\tau) \in \mathrm{T} \\
& \mathrm{Zt}^{*}=\inf \mathrm{Z}_{-} \mathrm{t}(\tau) \\
& (\tau) \in \mathrm{T} \\
& \mathrm{Z}_{-} \alpha^{*}=\text { inf } \mathrm{Z}_{-} \alpha(\tau) \\
& (\tau) \in \mathrm{T}
\end{aligned}
$$

The null hypothesis of no cointegration is tested first by running regression of Eqs. (3) and (4) for each possible structural break $\tau \in T=(0.15,0.85)$ in the case of $\mathrm{GH}$ test and $\tau_{1} \in T_{1}=(0.15,0.70)$ and $\tau_{2} \in T_{2}=\left(0.15+\tau_{1}, 0.85\right)$ for $\mathrm{HJ}$ test. Then applying (5)-(7) for regression errors of each possible structural break. The smallest value of (5)-(7) is chosen to compare against the critical values of one -break point and two - break point test developed by $\mathrm{GH}$ and $\mathrm{HJ}$, respectively, to accept and reject the null hypothesis of no cointegration. 


\section{Macrothink \\ Journal of Social Science Studies \\ ISSN 2329-9150 \\ 2018, Vol. 5, No. 1}

\section{Empirical Results and Discussions}

In order to analyse the stochastic properties of the series under study, unit roots test have been performed. Augmented Dicky Fuller Tests, Phillip-Perron test and DF GLS Test have been applied. Table 2 shows the results of these tests. The results reveal that all series are non-stationary at levels but are stationary at first difference. The results of Zivot-Andrews unit roots have also been performed (see Table 3). ZA test identified three breaks dates of 1995, 1982 and 1998 in model C. Model C shows the intercepts and trend both in the series.

Table 2. Unit root tests

\begin{tabular}{|c|c|c|c|c|c|c|}
\hline & \multicolumn{2}{|c|}{$\begin{array}{l}\text { ADF Test } \\
\text { (Intercept and Trend) }\end{array}$} & \multicolumn{2}{|c|}{$\begin{array}{l}\text { PP Test } \\
\text { (Intercept and Trend) }\end{array}$} & \multicolumn{2}{|c|}{$\begin{array}{l}\text { DF GLS Test } \\
\text { (Intercept and Trend) }\end{array}$} \\
\hline & Level & First -diff & Level & First -diff & Level & First -diff \\
\hline $\mathrm{CO} 2$ & -3.08387 & $-6.132453 * * *$ & -3.0839 & $-6.33883 * * *$ & -2.75723 & $-6.0811 * * *$ \\
\hline Y & -0.98416 & $-5.507032 * * *$ & -1.7958 & $-3.548821 * *$ & -2.19239 & $-3.2056^{* *}$ \\
\hline Y2 & -1.00858 & $-5.648971 * * *$ & -1.8145 & $-3.540837 * *$ & -2.18421 & $-3.2143 * *$ \\
\hline EN & -2.78131 & $-3.255526^{*}$ & -1.5415 & $-5.032135 * * *$ & -2.17563 & $-3.816^{* * *}$ \\
\hline TO & -2.64046 & $-8.845933 * * *$ & -2.6839 & $-9.082058 * * *$ & -2.64021 & $-8.7139 * * *$ \\
\hline
\end{tabular}

Note: ***, **, * significant at 1\%, 5\% \& $10 \%$ repectively.

Table 4 reports the calculation of F-statistics by bound testing procedure based on the selected ARDL models. The optimal order of lag length selected by the model is based on Akaike (AIC) information criteria. The bound test indicates the presence of cointegration when $\mathrm{CO} 2$ is dependent variable. This is because the result shows that $F_{\mathrm{CO}_{2}}\left(\mathrm{CO}_{2} \mid Y, Y^{2}, E N, T O\right)=5.361$ is higher than the upper critical value of F-statistics at $1 \%$ level of significance. Therefore we reject the null hypothesis of no cointegration in favour of alternative hypothesis of long run relationship among the variables specified in Equation (1). 
Table 3. ZA unit root tests

\begin{tabular}{lllllll}
\hline & Model A & \multicolumn{3}{c}{ Model B } & \multicolumn{3}{c}{ Model C } \\
\hline & t-Stat & Break year & t-Stat & Break year & t-Stat & Break year \\
$\mathrm{CO}_{2}$ & -3.8915 & 1995 & -3.8162 & 2000 & -4.9427 & 1995 \\
$\mathrm{Y}$ & -4.6783 & 1982 & -3.6227 & 1986 & -4.6395 & 1982 \\
$\mathrm{Y} 2$ & -4.7546 & 1982 & -3.6853 & 1986 & -4.732 & 1982 \\
$\mathrm{EN}$ & --- & --- & -7.2734 & 1982 & ---- & --- \\
$\mathrm{TO}$ & -5.054 & 2004 & -5.397 & 1999 & -5.2901 & 1998 \\
\hline
\end{tabular}

The result of Threshold cointegration test with regime shift are reported in Table 5. It shows that the modified ADF and $Z_{a}{ }^{*}$ and $Z_{t} *$ test reject the null hypothesis of no cointegration at $5 \%$ level of significance for Gregory-Hansen test of single breakpoint but in case of two break point of Hatemi-J (HJ) test, it does not confirm the results. The critical values for $\mathrm{GH}$ and HJ tests are available in GH (1996) and HJ (2008). The Threshold cointegration test for single break confirms the long run relationship between carbon emissions and rest of the variables in the equation.

Table 4. ARDL cointegration bound testing approach for the model

\begin{tabular}{llll}
\hline ARDL Function & Optimal lag length & F- statistics & Inference \\
\hline$F_{\mathrm{CO}_{2}}\left(C \mathrm{C}_{2} \mid Y, Y^{2}, E N, T O\right)$ & $4,4,4,3,4$ & $5.361^{* * *}$ & Cointegration \\
\multirow{2}{*}{ Significance level } & Critical Bound F- Values & \\
& Lower & Upper & \\
$1 \%$ & 3.29 & 4.37 & \\
$5 \%$ & 2.56 & 3.49 & \\
$10 \%$ & 2.2 & 3.09 & \\
\hline
\end{tabular}

Note: ***computed statistics falls above the upper bound value at $1 \%$ level of significance. 
Table 5. Threshold cointegration results with Regime Shift

\begin{tabular}{llll}
$\mathrm{F}_{\mathrm{CO}_{2}}\left(\mathrm{CO}_{2} \mid Y, Y^{2}, E N, T O\right)$ & $\mathrm{ADF}^{*}$ & $\mathrm{Zt}^{*}$ & $\mathrm{Z} \alpha^{*}$ \\
\hline $\mathrm{GH}$ test & $-11.03^{* *}$ & $-11.1^{* *}$ & -67.5 \\
$\mathrm{HJ}$ test & -5.71 & -5.77 & -37.47 \\
& $(0.41,0.48)$ & $(0.14,0.31)$ & $(0.14,0.31)$ \\
\hline
\end{tabular}

** Significant at 5\% level of significance. The critical values for $\mathrm{GH}$ and $\mathrm{HJ}$ tests are available in GH (1996) and HJ (2008).

With the given existence of long-run relationship, the ARDL cointegration methodology is used to estimate the parameters of Equation (1). The error correction coefficient is negative $(-1.23)$ as required and very significant and its magnitude is quite high indicating a fast return to equilibrium in case of disequilibrium.

Table 6. Long run coefficients based on ARDL cointegration results

\begin{tabular}{lc}
\hline Variables & Coefficients \\
\hline Y & $-39.85(-1.10)$ \\
Y2 & $2.03(1.09)$ \\
EN & $0.11(1.32)$ \\
TO & $1.20(2.69)$ \\
Constant & $191.38(1.10)$ \\
\hline
\end{tabular}

Author calculation. Figures in brackets are t- Statistics.

The coefficients of the variables are not statistically significant except in case of trade openness. The long run elasticity of $\mathrm{CO}_{2}$ emissions, with respect to energy consumption is 0.11 pointing that for each $1 \%$ increase in per capita energy, per capita $\mathrm{CO}_{2}$ emission rise by 0.11 percent. The elasticity of $\mathrm{CO}_{2}$ emissions with respect to trade openness in the long run is 1.2 indicating high contribution in $\mathrm{CO}_{2}$ during the estimation period. The statistically insignificance of square of per capita real income with positive sign shows that Saudi economy does not support the EKC hypothesis.

\section{Conclusions}

This paper has tried to analyse the relationship between CO2 emission, energy consumption, income and trade openness for Saudi Arabia by using the model provided by Halicioglu, F. The study used the ARDL bound test approach which confirms the existence of cointegration among the variables. Further, the study also examines the cointegrating relationship for Saudi Arabia using threshold cointegrating tests of Gregory- Hansen (1996) single structural break and two structural break Regime Shift model of Hatemi-J (2008) with an observation to test the EKC hypothesis. In case of ARDL model and single structural break model, there is presence of 
cointegration among the variables but in case of two -structural break Regime Shift, there is no cointegration.

\section{References}

Abosedra, S., \& Baghestani, H. (1989). New evidence on the causal relationship between United States energy consumption and gross national product. Journal of Energy and Development, 14, 285-292.

Akarca, A. T. (1980). On the relationship between energy and GNP: a reexamination. Journal of Energy and Development, 5, 326-331.

Akbostanci, E., Turut-Asik, S., \& Tunc, G. I. (2009). The relatioship between income and environment in Turkey: is there an environmental Kuznet;s curve? Energy Policy, 37(3), 861-867. https://doi.org/10.1016/j.enpol.2008.09.088

Akinlo, A. (2008). Energy consumption and economic growth: evidence from 11 African countries. Energy Economics, 30, 2391-2400. https://doi.org/10.1016/j.eneco.2008.01.008

Altinay, G., \& Karagol, E. (2004). Structural break ,unit root, and the causality between energy consumption and GDP in Turkey. Energy Economics, 26, 985-994. https://doi.org/10.1016/j.eneco.2004.07.001

Ang, J. (2008). Economic development ,pollutant emissions, and energy consumption in Malaysia. Journal of Policy Modelling, 30, 271-278. https://doi.org/10.1016/j.jpolmod.2007.04.010

Apergis, N., \& Payne, J. E. (2009). Energy consumption and economic growth in Central America: evidnece from panel cointegration and error correction model. Energy Economics, 31, 211-216. https://doi.org/10.1016/j.eneco.2008.09.002

Bentzen, J., \& Engsted,T. (1993). Short-and long- run elasticities in energy demand. Energy Economics, 15, 9-16. https://doi.org/10.1016/0140-9883(93)90037-R

Boden, T. G. (2011). Global, Regional, and National Fossil-Fuel Co2 Emission. Oak, Ridge Tenn U.S.A.: Carbon Dioxide Information Analysis Centre, Oak Ridge National Laboratory, U.S. Department of Energy.

Brown, S. P. A., \& Yucel, M. K. (2002). Energy prices and aggregate economic activity: an interpretive survey. The Quarterly Review of Economics and Finance, 42, 193-208. https://doi.org/10.1016/S1062-9769(02)00138-2

Coondoo, D., \& Dinda, S. (2008). The carbon dioxide emission and income: a temporal analysis of cross-country distribunal patterns. Ecological Economics, 65, 375-385. https://doi.org/10.1016/j.ecolecon.2007.07.001

Dickey, D. A., \& Fuller, W. A. (1981). Likelihood ratio statistics for autoregressive time series with a unit root . Econometrica, 49, 1057-1072. https://doi.org/10.2307/1912517

Dinda, S. (2004). Environmental Kuznet;s curvehypothesis: a survey. Ecological Economics, 49, 431-455. https://doi.org/10.1016/j.ecolecon.2004.02.011

Dinda, S., \& Coondoo, D. (2006). Income and emission: a panel data-based cointegration analysis. Ecological Economics, 57, 167-181. https://doi.org/10.1016/j.ecolecon.2005.03.028

Dtern, D. (2004). The rise and fall of environmental Kuznet;s curve. World Development, 32(8), 1419-1439. https://doi.org/10.1016/j.worlddev.2004.03.004 
Elliott, G. (1996). Efficient tests for an autoregressive unit root. Econometrica, 64, 313-836. https://doi.org/10.2307/2171846

Engle, R., \& Granger, C. (1987). Cointegration and error correction representation: estimation and testing. Econometrica, 55, 251-276. https://doi.org/10.2307/1913236

Erol, U. Y. (1987). On the causal relationship between energy and income for industrialized countries. Journal of Energy and Development, 13, 113-122.

Friedl, B., \& Getzner, M. (2003). Determinants of CO2 emissions in a small open economy. Ecological Economics, 45, 133-148. https://doi.org/10.1016/S0921-8009(03)00008-9

Ghali, K. H., \& El-Sakka, M. I. T. (2004). Energy use and output growth in Canada: a multivariate cointegration analysis. Energy Economics, 26(2), 225-238. https://doi.org/10.1016/S0140-9883(03)00056-2

Ghosh, S. (2010). Examining carbon emissions and economics growth nexus for India: a multivariate cointegration approach. Energy Policy, 38, 3008-3014. https://doi.org/10.1016/j.enpol.2010.01.040

Gregory, A. W., \& Hansen, B. E. (1996). Tests for cointegration in models with regime change and trend shifts. Oxford Bulletin of Economics and Statistics, 58, 555-560. https://doi.org/10.1111/j.1468-0084.1996.mp58003008.x

Grossman, G., \& Krueger, A. (1991). Environmental impacts of a North American Free Trade Agreement . Cambridge: National Bureau of Economics Research Working Paper, No. 3194, NBER. https://doi.org/10.3386/w3914

Halicioglu, F. (2009). An econometric study of $\mathrm{CO}_{2}$ emissions, energy consumtion, income and foreign trade in Turkey. Energy Policy, 37, 1156-1164. https://doi.org/10.1016/j.enpol.2008.11.012

Hatemi, J. A. (2008). Tests for cointegration with two unknown regime shifts with an application to financial market integration. Empirical Economics, 35(3), 497-505. https://doi.org/10.1007/s00181-007-0175-9

Heil, M. T., \& Selden, T. M. (1999). Panel stationarity with structural breaks: carbon emission and GDP. Applied Economic Letters, 6, 223-225. https://doi.org/10.1080/135048599353384

Huang, B., Hwang, M. J., \& Yang, C. W. (2008). Causal relationship between energy consumption and GDP growth revisited: a dynamic panel data approach. Ecological Economics, 67, 41-54. https://doi.org/10.1016/j.ecolecon.2007.11.006

Jalil, A., \& Mahmud, S. F. (2009). Environment Kuznet's curve for $\mathrm{CO}_{2}$ emissions: a cointegration analysis for China. Energy Policy. https://doi.org/10.1016/j.enpol.2009.07.044

Johansen, S., \& Juselius, K. (1990). Maximum likelihood estimation and inference on cointegration -with application to the demand for money. Oxford Bulletin of Economics and Statistics, 52, 169-210. https://doi.org/10.1111/j.1468-0084.1990.mp52002003.x

Kanjilal, K., \& Ghosh, S. (2013). Environmental Kuznet's curve for India: Evidence from tests for cointegration with unknown structural breaks. Energy Policy, 56, 509-515. https://doi.org/10.1016/j.enpol.2013.01.015 


\section{I Macrothink}

Journal of Social Science Studies

ISSN 2329-9150

2018, Vol. 5, No. 1

Kraft, J. K. (1978). On the relationship between energy and GNP. Journal of Energy and Development, 3, 401-403.

Managi,S., Jena, P.R. (2007). Productivity and environment in India . Economics Bulletin 17(1), 1-14.

Mansure Masih A. M., \& Mello, L. D. (2011). Does the Environmental Kuznet's curve exit? An application of long run structural modelling to Saudi Arabia. Economia Internazionale $n$ 2 .

Narayan, P. (2004). Reformulating Critical Values for the Bounds F-Statistics Approach to Cointegration: An Application to the Tourism Demand Model for Fiji. Melbourne, Australia: Department of Economics Discussion Papers No. 02/04, Monash University, .

Narayan, P. (2005). The saving and investment nexus for China: evidence from cointegration tests. Applied Economics, 37, 1979-1990. https://doi.org/10.1080/00036840500278103

Narayan, P. K., \& Smyth, R. (2005). Electricity consumption employment real income in Australia evidence from multivariate Granger causalitytest. Energy Policy, 33(9). https://doi.org/10.1016/j.enpol.2003.11.010

Oh. W., \& Lee, K. (2004). Causal relationship between energy consumption and GDP revisited; the case of Korea1970-1999. Energy Economics, 26, 51-59. https://doi.org/10.1016/S0140-9883(03)00030-6

Perron, P. (1989). The great crash, the oil price shock, and the unit root hypothesis. Econometrica, 57, 1361-1401. https://doi.org/10.2307/1913712

Pesaran, M. H., \& Shin, Y. (1998). Generalised impulse response analysis in linear $\begin{array}{lllll}\text { multivariate } \quad \text { models. } & \text { Econometrics } & \text { Letters, } & \text { 58, }\end{array}$ https://doi.org/10.1016/S0165-1765(97)00214-0

Pesaran, M. H., Shin, Y., \& Smith, R. (2001). Bounds testing approaches to the analysis of level relationships. Journal of Applied Econometrics 16, 289-326. https://doi.org/10.1002/jae.616

Phillips, P. C. B., \& Perron, P. (1988). Testing for a unit in time series regression. Biometrika 75, 335-346. https://doi.org/10.1093/biomet/75.2.335

Rahman, S. (2012). Mitigation measures to reduce greenhouse gas emission and enhance carbon capture and storage in Saudi Arabia. Renewable andsustainable. Energy Reviews, 16(5), 2446-2460. https://doi.org/10.1016/j.rser.2011.12.003

Romero-Avila, D. (2008). Questioning the empirical basis of the environmental Kuznet's curve for $\mathrm{CO} 2$ : new evidence from a panelstationaroty test, robust to multiple breaks and $\begin{array}{llll}\text { cross }=\text { dependence } & \text { Ecological } & \text { Economics, } & 64(3),\end{array}$ https://doi.org/10.1016/j.ecolecon.2007.03.011

Shafik, N. (1994). Economic development and environmental quality: an economic analysis. Oxford Economic Papers, 46, 757-773. https://doi.org/10.1093/oep/46.Supplement_1.757

Soytas, U., \& Sari, R. (2009b). Energy consumption, economic growth, and carbon emissions: challenges faced by an EU candidate member. Ecological Economics, 68(6), 1667-1675. https://doi.org/10.1016/j.ecolecon.2007.06.014 
Soytas, U., \& Sari, R. (2003). Energy consumption and GDP: causality relationship in G-7 countries and emerging markets. Energy Economics, 25, 33-37. https://doi.org/10.1016/S0140-9883(02)00009-9

Soytas, U., \& Sari, R. (2006). Energy consumption and income in G-7 countries. Journal of Policy Modeling, 28(7), 739-750. https://doi.org/10.1016/j.jpolmod.2006.02.003

Soytas, U., \& Sari, R. (2009). Energy consumption, economic growth, and carbon emissions: challenges faced by an EU candidate member. Ecological Economics, 68(6), 1667-1675. https://doi.org/10.1016/j.ecolecon.2007.06.014

Soytas, U., Sari, R., \& Ewing, B. T. (2007). Energy consumption, income, and carbon emission in the United States. Ecological Economics, 62, 482-489. https://doi.org/10.1016/j.ecolecon.2006.07.009

Stern, D. (1993). Energy use and economic growth in the USA: a multivariate approach. Energy Economics, 15, 137-150. https://doi.org/10.1016/0140-9883(93)90033-N

Stern, D. (2000). A multivariate cointegration analysis of the role of energy in the US macroeconomy. Energy Economics, 267-283. https://doi.org/10.1016/S0140-9883(99)00028-6

Stern, D. (2004). The rise and fall of the environmental Kuznet's curve. World Development, 32(8), 1419-1439. https://doi.org/10.1016/j.worlddev.2004.03.004

Turner, P. (2006). Response surfaces for an F-test for cointegration. Appliedd Economic Letters, 13(8), 479-482. https://doi.org/10.1080/13504850500401726

Wolde-Rufael, Y. (2005). Energy demand and economic growth : the African experience 19 countries. Journal of Policy Modeling, 27(8), 891-903. https://doi.org/10.1016/j.jpolmod.2005.06.003

Yu, E. C. (1985). The causal relationship between energy and GNP: an international comparision. Journal of Energy and Development, 10, 249-272.

$\mathrm{Yu}$, E. H. (1984). The relationship between energy and GNP: further results. Energy Economics, 6, 186-190. https://doi.org/10.1016/0140-9883(84)90015-X

Zhang, X. P., \& Cheng, X. M. (2009). Energy consumption, carbon emission and economic growth in China. Ecological Economics, 68(10), 2706-2712. https://doi.org/10.1016/j.ecolecon.2009.05.011

\section{Copyright Disclaimer}

Copyright for this article is retained by the author(s), with first publication rights granted to the journal.

This is an open-access article distributed under the terms and conditions of the Creative Commons Attribution license (http://creativecommons.org/licenses/by/3.0/). 